\title{
Diffuse urban pollution increases metal tolerance of natural heterotrophic biofilms
}

\author{
Lise C. Fechner $^{\mathrm{a}, \mathrm{b},{ }^{*} \text {, Catherine Gourlay-Francé }}{ }^{\mathrm{a}, \mathrm{b}}$, Adeline Bourgeault ${ }^{\mathrm{a}, \mathrm{b}}$, \\ Marie-Hélène Tusseau-Vuillemin ${ }^{c}$
}

\author{
a Cemagref- Unité de Recherche Hydrosystèmes et Bioprocédés, Parc de Tourvoie, BP 44, F 92163 Antony \\ Cedex, France \\ ${ }^{\mathrm{b}}$ FIRE, FR-3020, 4 Place Jussieu 75005, Paris, France \\ c IFREMER, Technopolis 40, 155 Rue Jean-Jacques Rousseau, 92138 Issy-Les-Moulineaux, France \\ *: Corresponding author : Lise C. Fechner, email address : lise.fechner@cemagref.fr
}

\begin{abstract}
:
This study is a first attempt to investigate the impact of urban contamination on metal tolerance of heterotrophic river biofilms using a short-term test based on $\beta$-glucosidase activity. Tolerance levels to $\mathrm{Cu}, \mathrm{Cd}, \mathrm{Zn}, \mathrm{Ni}$ and $\mathrm{Pb}$ were evaluated for biofilms collected at three sites along an urban gradient in the Seine river (France). Metallic pollution increased along the river, but concentrations remained low compared to environmental quality standards. Biofilm metal tolerance increased downstream from the urban area. Multivariate analysis confirmed the correlation between tolerance and contamination and between multi-metallic and physico-chemical gradients. Therefore, tolerance levels have to be interpreted in relation to the whole chemical and physical characteristics and not solely metal exposure. We conclude that community tolerance is a sensitive biological response to urban pressure and that mixtures of contaminants at levels lower than quality standards might have a significant impact on periphytic communities.
\end{abstract}

\section{Highlights}

A new short-term test based on $\beta$-glucosidase activity to assess biofilm metal tolerance. $>\mathrm{Cd}$, $\mathrm{Cu}$, $\mathrm{Ni}, \mathrm{Pb}$ and $\mathrm{Zn}$ tolerance of natural biofilms collected along an urban gradient. Metal tolerance levels increase upstream to downstream the river. Community tolerance increases at environmental quality standard exposure concentrations. Biofilm tolerance is a sensitive biological response to diffuse urban pollution.

Keywords: Metal tolerance ; Beta-glucosidase ; Freshwater biofilm ; ARISA ; Environmental quality standards ; PICT ; Heterotrophic communities 


\section{Introduction}

Over the past decades, human activities in urban areas have contributed to the increase of chemical contamination of aquatic ecosystems (Meybeck, 2003). Typical urban pollution can be described as a mixture of contaminants at low, sublethal concentrations (Tusseau-Vuillemin et al., 2007). It is difficult to evaluate the long-term biological consequences of such diffuse, chronic contamination as it does not engender easily-detectable biological responses in situ (Beasley and Kneale, 2004; Bourgeault et al., 2010). The distinction between chemical-induced changes and changes due to other causes is not always clear as endpoints used to evaluate toxicity may vary due to environmental and/or biological variability (Blanck et al., 1988; Sabater et al., 2007; Soldo and Behra, 2000). Assessment of the impacts of urban contaminants in the field therefore requires the use of efficient tools to link biological impairment to chemical contamination.

The PICT (Pollution-Induced Community Tolerance) approach was proposed as an efficient ecotoxicological tool to relate tolerance acquisition at the community level to exposure to toxicants (Blanck, 2002; Blanck et al., 1988). It relies on the assumption that sensitive components of the exposed community (species, genotypes or phenotypes) will be replaced by more tolerant ones during exposure, thus leading to an increase of community tolerance. Tolerance development can be measured as a shift in the Effect Concentration (usually $\mathrm{EC}_{50}$ ) that is obtained with a short-term toxicity test based on a physiological endpoint. In particular, the PICT approach was proposed as a tool to demonstrate causative links between toxicants and their adverse biological effects (tolerance levels), due to its ability to discriminate between selection pressures (Blanck et al., 2009), although co-tolerance phenomenons might confound interpretation of the results (Blanck, 2002).

Biofilms (or periphyton) are complex, natural assemblages of micro-organisms that develop on submerged substrata. They typically consist of bacteria, micro-algae, protozoa and fungi embedded in a polymeric matrix. Because of their short-generation time, these micro-organismes respond quickly to disturbances and are thus regarded as early-warning indicators to detect the effects of toxicants (Sabater et al., 2007). Moreover, biofilms provide a community-level perspective on biological responses, which is more ecologically relevant to assess the impacts of contaminants than data obtained from single-species tests (Clements and Rohr, 2009; Lehmann et al., 1999; McClellan et al., 2008). The PICT methodology has been applied using natural biofilms to link tolerance levels to river contamination for instance with herbicides (Pesce et al., 2010), using photosynthetic activity as endpoint in toxicity tests, or with Zn, with both photosynthetic and bacterial activity (measured as thymidine incorporation), as endpoints (Blanck et al., 2003). Yet ecotoxicological investigations attempting to link the biological responses of collected organisms to the presence of stressors in the field remain scarce (Clements et al., 2002). 
Most PICT studies have focused on tolerance measurements of phototrophic algal communities (periphyton or phytoplankton) exposed to herbicides or $\mathrm{Cu}$ (for instance Blanck et al., 2009; Guasch et al., 1998; McClellan et al., 2008; Serra et al., 2010). However, in urban fluvial ecosystems, heterotrophic communities play an important ecological role, in particular in bio-mineralization processes. Hence, exoenzymes, which control essential metabolic pathways, are interesting to study the effects of environmental perturbation on the functioning of aquatic ecosystems (Admiraal and Tubbing, 1991). In particular, $\beta$ glucosidase activity represents the activity of heterotrophic micro-organisms (Chrost, 1991). It is therefore an interesting endpoint for short-term tests designed to measure the tolerance of heterotrophic communities. Moreover, several toxicicy tests used in PICT studies are performed using radioactive reagents such as labeled-thymidine for measurements of bacterial growth or labeled- $\mathrm{CO}_{2}$ for photosynthesis measurements (see for instance Blanck et al., 2003). $\beta$-glucosidase activity, in contrast, can be measured using non-toxic fluorescent susbtrates. Recently, it was successfully used as the endpoint in toxicity tests measuring the tolerance to metals of natural freshwater biofilms (Fechner et al., 2010a). Additionally, this short-term test was shown to be a fast and sensitive means to measure biological effects at the community level in microcosms' experiments in which biofilms were exposed to metals ( $\mathrm{Cd}, \mathrm{Ni}$ and $\mathrm{Zn}$ ) at environmental levels (Fechner et al., 2011a). Since sewers and road and roof run-offs are major metal contamination sources (Thévenot et al., 2007), metals are important to consider when trying to assess the impact of urban contaminations.

The objective of our study is to detect pollution-induced effects on fluvial biofilms collected in a typical urban river (the Seine river, France), under chronic, multi-metallic exposure at low, environmental concentrations. For that purpose, we used the recently-developed short-term toxicity test based on $\beta$ glucosidase activity to detect differences in $\mathrm{Cu}, \mathrm{Cd}, \mathrm{Ni}, \mathrm{Pb}$ and $\mathrm{Zn}$ tolerance levels of the heterotrophic component of fluvial biofilms collected in situ.

\section{Material and Methods}

Biofilms were collected along the Seine river (France) upstream (site 1) and downstream (sites 2 and 3) from the Paris urban area after several weeks of in-situ colonization. Biofilms were analyzed using general descriptors such as dry weight (DW), ash-free dry weight (AFDW) and chlorophyll $a$ (Chl-a) concentrations and biofilm tolerance to metals $(\mathrm{Cu}, \mathrm{Cd}, \mathrm{Ni}, \mathrm{Pb}$ and $\mathrm{Zn}$ ) was evaluated using short-term toxicity tests based on $\beta$-glucosidase activity. Modifications of both bacterial and eukaryotic community structures were also assessed with ARISA (Automated-Ribosomal Intergenic Spacer Analysis) fingerprints. Multivariate analysis was then used to study the correlations between tolerance and metal contamination. 
Study sites

Biofilms were collected on three sites located along the Seine river (North of France). Site 1 (Marnay-surSeine) was located in a non-urbanized area, approximately $200 \mathrm{~km}$ upstream from Paris (Strahler: 6, median annual flow $50 \mathrm{~m} 3 / \mathrm{s}$ ), and sites 2 (Bougival, Strahler: 7, mean annual flow $184 \mathrm{~m} 3 / \mathrm{s}$ ) and 3 (Triel-sur-Seine, Strahler: 8, mean annual flow $340 \mathrm{~m} 3 / \mathrm{s}$ ) were both downstream from Paris. In particular, site 3 was located about $20 \mathrm{~km}$ downstream the discharge of the sewer treatment plant Seine-Aval (nominal capacity $810^{6}$ inhabitants, flow $24 \mathrm{~m} 3 / \mathrm{s})$. Total, dissolved and labile metal concentrations, as well as 15 physico-chemical parameters were monitored monthly at the three sites over one year (Priadi et al., 2011). Only the data collected over the period corresponding to this study (3 samplings from May to July 2009, with one sample for total and dissolved metal concentrations and for physico-chemical parameters at each sampling date)

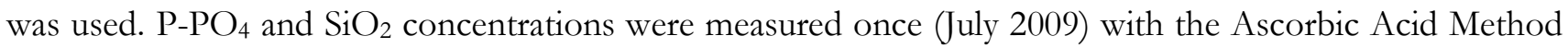
and the Silicomolybdate Method respectively. Each labile metal concentration corresponds to three Diffusive Gradients in Thin films (DGTs) (Zhang and Davison, 1995) immersed in the river during one month (Priadi et al., 2011). DGTs provide an estimate of time-weighted average concentrations of inorganic and weakly-complexed dissolved metals (Tusseau-Vuillemin et al., 2007).

\section{Collection of periphytic communities}

Biofilms were grown on Low Density PolyEthylene membranes (approximately $15 * 30 \mathrm{~cm}^{2}$ ) vertically attached to plastic crates as in Fechner et al. (2010a). On day 0, 10 membranes were immersed in the river at each site. After 28, 35 and 42 days of colonization, 2 to 3 colonized membranes were collected from each sampling site and carried back to the laboratory in $250 \mathrm{~mL}$ glass-bottles placed in a cooler. Membranes were then hand-scraped to collect periphyton and make biofilm suspensions in mineral water (Grand Barbier, Mont-Dore, France) as in Fechner et al. (2010a). Biofilms scraped from the membranes collected at one site were pooled together to provide a unique biofilm suspension for each date and each site. Aliquots of the biofilm suspensions were then assigned to various analyses for periphyton characterization or tolerance measurements. To obtain bacterial and eukaryotic Automated Ribosomal Intergenic Spacer Analysis (ARISA) fingerprints of each biofilm sample, aliquots of biofilm suspensions were centrifuged (15 minutes, $10000 \mathrm{~g}, 4^{\circ} \mathrm{C}$. Supernatants were discarded and pellets were stored at $-80^{\circ} \mathrm{C}$ for further use. 


\section{Biofilm chemical characterization}

At each sampling date, biofilm DWs, AFDWs and Chl-a concentrations were measured in triplicate as in Fechner et al. (2010b). C/N ratios were calculated from the particulate organic carbon and nitrogen (POC and PON) concentrations in the biofilm suspensions. POC and PON were determined from biofilm pellets (centrifugation: 2000g, 15 minutes), after acidic digestion ( $\mathrm{HCl}, 10 \%$ ), with a carbon analyzer (VarioELIII, Elementar, Germany) in triplicate. Concentrations of total accumumated metals were measured in the biofilms collected on day 35 as in (Fechner et al., 2011a). Acumulated metal concentrations were analyzed with an Inductively-Coupled Plasma-Mass Spectrophotometer (ThermoFisher Scientific). The accuracy and the precision of the measuring device were regularly controlled with certified reference natural water samples (NIST 1640).

\section{ARISA fingerprinting of biofilms}

ARISA fingerprints were obtained at each sampling date as in Fechner et al. (2010b). Briefly, DNA was extracted from biofilm pellets using the Power Soil DNA Isolation Kit (Mobio Laboratories, Inc., Carlsbad, US). PCR amplification of bacterial 16S-23S ITS was performed using primers ITSF/ITSReub (Cardinale et al., 2004) and amplification of eukaryotic ITS1-5.8S-ITS2 regions was performed using primers 2234C/3126T (set euk, appropriate to study eukaryotes: algae, ciliates, etc.) (Ranjard et al., 2001) and ARAlg18S/ITS4 (Fechner et al., 2010b) (set diat, more specific to diatoms). Amplicons were separated on an electrophoresis Bioanalyzer (2100 Electrophoresis Bioanalyzer, Agilent Technologies) and fluorescence data was converted into electrophoregrams using 2100 Expert software (Agilent Technologies). Electrophoregrams were processed using the StatFingerprints R package (Michelland et al., 2009). To compare efficiently fingerprint profiles, the area under each curve was normalized to 1 and proximities between pairs of fingerprinting profiles were calculated using the Manhattan distance (Lear and Lewis, 2009). The distance matrix thus constructed was analyzed using nMDS - non metric multidimensional scaling - in order to visualize similarities in community structure in 2D. NMDS constructs a twodimensional map showing each fingerprint (ARISA profile) as one plot so that highly similar fingerprints are plotted together. A stress value is used to compute a goodness of fit analysis between the reproduced (in the map) and the actual distances. A stress value $<0.1$ corresponds to a good ordination (Clarke, 1993). 
The tolerance to metals $(\mathrm{Cd}, \mathrm{Cu}, \mathrm{Ni}, \mathrm{Pb}, \mathrm{Zn})$ of heterotrophic biofilm micro-organisms was assessed using the normalized $\mathrm{EC}_{50}$ values obtained with the toxicity test based on $\beta$-glucosidase activity developed by Fechner et al. (2011a; 2010a). Briefly, biofilms were exposed for one hour to acute concentrations of metals (at least six concentrations of metal varying between 0.001 and $10 \mathrm{mM}$ were tested in triplicate for each toxicity test). Metal exposure levels during the toxicity tests were checked by measuring metal concentrations in the stock solutions by flame AAS (Varian Inc., USA). After one hour of exposure, $\beta$ glucosidase activity of the metal-exposed biofilms was measured spectrofluorometrically using Methylumbelliferyl- $\beta$-D-glucopyranoside $\quad$ (MUF-GLU) (Sigma-Aldrich). $\quad$ Fluorescence of 4Methyllumbelliferone (MUF) was measured using an LB 941 Tristar Ti fluorescence microplate reader (Berthold Technologies, Bad Wildbad, Germany) (excitation/emission filters: 355 and $460 \mathrm{~nm}$ ). Fluorescence measurements were converted into MUF concentrations by calibrating the spectrofluorimeter with a range of MUF solutions prepared in demineralised water. $\%$ inhibition of $\beta$-glucosidase activity was then calculated using MUF concentrations measured for each metal concentration tested. $50 \%$ effect concentrations $\left(\mathrm{EC}_{50}\right)$ and maximum inhibition levels were determined from the dose/effect curves, which were obtained by plotting the $\%$ inhibition of $\beta$-glucosidase activity as a function of metal concentration, and by fitting the data to the Hill model (Hill, 1910; Vindimian, 2001). The general form of the curve fitted on the data is:

$$
F(x)=\% \max \times \frac{x^{H}}{x^{H}+E C_{50}{ }^{H}}
$$

where $\mathrm{x}$ is the metal concentration, $\% \max$ is the predicted effect when the toxicant concentration is infinite, and $\mathrm{H}$ is the Hill number (slope of the toxicity curve). Each parameter (\%max, $\mathrm{EC}_{50}$ and $\mathrm{H}$ ) was adjusted for the calculation by non-linear regression. 95\% confidence intervals around the fitted parameters were estimated using a Bootstrap method. Parameters ( $\mathrm{EC}_{50}$ values and maximum \% inhibition) were considered significantly different when $95 \%$ confidence intervals were not overlapping.

Community tolerance to metals was assessed by calculation of a normalized $\mathrm{EC}_{50}$ value by dividing the $\mathrm{EC}_{50}$ value by the Total Suspended Solids (TSS) concentration of the periphyton suspension used for the short-term test (Fechner et al., 2010a). TSS-normalized EC 50 values provide a reliable and robust estimation of metal tolerance and do not depend on experimental conditions.

$\mathrm{Cu}$ tolerance levels were measured on the biofilms collected on day 28 at the three sites, $\mathrm{Cd}$ and $\mathrm{Zn}$ tolerance levels on the biofilms collected on day 35, and $\mathrm{Ni}$ and $\mathrm{Pb}$ tolerance levels on the biofilms collected on day 42 . 


\section{Statistical analyses}

The influence of the environmental parameters on biofilm tolerance levels and biofilm parameters was investigated using Principal component analysis (PCA). The data was log-transformed and normalized before analysis. Statistical analyses were performed using XLStat 2010 (Addinsoft, France).

\section{Results}

\section{Environmental data upstream to downstream the river}

An increase in metallic concentrations was revealed between site 1 (upstream) on the one hand and sites 2 and 3 (downstream from Paris) on the other hand. Mean metal concentrations (Figure 1) were always higher at the downstream sites, by a factor ranging from 1.3 (ratio of total $\mathrm{Ni}$ concentrations between site 1 and site 2) to 10.2 (ratio of total $\mathrm{Pb}$ concentrations between site 1 and site 2). Mean total $\mathrm{Cu}, \mathrm{Cd}, \mathrm{Pb}, \mathrm{Zn}$ and $\mathrm{Cr}$ as well as dissolved and labile $\mathrm{Pb}$ concentrations were higher at site 2 compared to site 3 , while the other mean metal concentrations were higher at site 3, even though the differences between both downstream sites were not statistically significant. Dissolved metal concentrations remained much lower than Environmental Quality Standards (EQSs) from the European Waterframework Directive for Cd, Ni and $\mathrm{Pb}$. For $\mathrm{Cu}$ and $\mathrm{Zn}$, dissolved metal concentrations were in the range of EQSs at both downstream sites (Table 1).

Mean physico-chemical parameters of the river water at the three sites (Table S1) during biofilm colonization in situ correspond to annual mean values reported elsewhere (Priadi et al., 2010). Except for calcium which remained stable and $\mathrm{pH}$ which tended to decrease upstream to downstream, all parameters tended to increase from site 1 to both downstream sites. It was not always possible to distinguish both downstream sites according to the values of the physico-chemical parameters. The impact of urbanization was reflected by high TSS, DOC, POC, nitrate and phosphate concentrations at sites 2 and 3.

\section{Biofilm characterization}

MDS analysis of ARISA fingerprints clearly groups biofilms according to the sampling sites (Figure 2). Both eukaryotic (Figure 2b) and bacterial (Figure 2a) communities reflect differences along the river, as ARISA 
fingerprints from both downstream sites are close together in the $2 \mathrm{D}$ plots. No clear pattern can be observed on eukaryotic fingerprints obtained using set diat for DNA amplification (Figure 2c), which is probably due to the high specificity of this primer set, resulting in a low number of fluorescence peaks on each fingerprint (Fechner et al., 2010b).

Biofilms could not be distinguished between site 1 on the one hand and both downstream sites on the other hand according to classical biofilm descriptors (Table 2). Biomass parameters were highest for the site 2 biofilms (DW, AFDW and Chl-a), but lowest for the site 3 biofilms at each sampling date.

Concentrations of metals accumulated within the biofilms reflected the increase of the multi-metallic exposure along the river as they were always lower for the site 1 biofilm, except in the case of $\mathrm{Ni}$ and $\mathrm{Cr}$ (Figure 3).

\section{Metal tolerance and maximum inhibition levels}

Dose/effect curves obtained from the toxicity tests are shown in Figure 4 (corresponding normalized $\mathrm{EC}_{50}$ values and $95 \%$ confidence intervals are given in Table 3). Normalized $\mathrm{EC}_{50}$ values increased along the river and remained similar for both downstream sites for $\mathrm{Cu}, \mathrm{Cd}$ and $\mathrm{Ni}$ as confidence intervals overlap. Metal tolerance levels of the three biofilms generally correlated well with in situ metal concentrations in the water (Pearson correlation coefficients appear in Table S2), except in the case of total $\mathrm{Zn}$ and total and labile $\mathrm{Pb}$. Maximum inhibition levels of $\beta$-glucosidase activity are also shown in Table 3. A maximum inhibition level below 100\% means that $\beta$-glucosidase activity cannot be fully inhibited during metal exposure even at high metal concentrations, which was already identified as a biological response to metal exposure in a previous microcosm study using the same toxicity test (Fechner et al., 2011a). In the present study, maximum inhibition levels tend to decrease upstream to downstream as tolerance increases (Table 3).

\section{PCA of biofilm parameters and metal concentrations}

The PCA plot is shown in Figure 5a. The first two components accounted for respectively $85.9 \%$ and 14.1 $\%$ of the total variance. Axis 1 reflected the urban gradient as it was positively correlated to metal concentrations (mostly the labile and dissolved metal concentrations) and physico-chemical parameters (only $\mathrm{pH}$ was negatively correlated to axis 1). Axis 2 reflected mostly the total metal concentrations ( $\mathrm{Pb}, \mathrm{Cr}$, $\mathrm{Cd}, \mathrm{Zn} \mathrm{Cu}$ ) and the labile $\mathrm{Pb}$ concentration. Sites 1, 2 and 3 were displayed along the first axis, according to the urban exposure gradient (Figure 5b). Site 2 appeared in the upper part of the plot as the total metal and 
labile lead concentrations were higher at this site. Figure $5 \mathrm{a}$ also shows that all tolerance values were positively correlated and that all the environmental parameters (metal concentrations and physico-chemical parameters) were positively correlated except for $\mathrm{pH}$. It also indicates a closer relationship between tolerance and dissolved and labile concentrations of $\mathrm{Cd}, \mathrm{Cu}$ and $\mathrm{Zn}$. PCA thus suggested that labile and dissolved metal concentrations provide a better estimation of the effective metal fraction inducing community tolerance to $\mathrm{Cd}, \mathrm{Cu}$ and $\mathrm{Zn}$ than total metal concentrations. Moreover, tolerance levels were not correlated to biofilm gross parameters (DW, AFDW, Chl-a).

\section{Discussion}

\section{Identifying the causes of tolerance acquisition in situ}

Identifying the biological impacts of toxic pressures is difficult in the field as toxicant-induced effects have to be discriminated from effects induced by other biotic or abiotic factors. Hence, identifying stressors and demonstrating a causative link between stressors and ecologically-relevant biological responses in the field remains a major scientific challenge for ecotoxicologists (Clements et al., 2002). The PICT approach proposes to evaluate community tolerance as a biological response to exposure to a toxicant (Blanck et al., 1988). Increase in tolerance is therefore considered to be directly linked to exposure to a specific stressor. However, proper identification of the factors that are responsible for community tolerance acquisition in situ remains difficult (Blanck et al., 2003; Pesce et al., 2010), and in particular in the present study where biofilms were collected in an area of diffuse, low-level multi-contamination. Indeed co-tolerance phenomenons and variations of both habitat characteristics (for instance light or water flow) and of physico-chemical parameters during exposure have to be taken into account to correctly interpret tolerance measurements.

PCA showed that there was a positive correlation between biofilm tolerance and the majority of environmental parameters, including both metals and physico-chemical parameters. This is not surprising as many parameters are inter-dependent, since urbanization induces a rise in both metal and nutrient concentrations. Variations of environmental parameters like light (Guasch et al., 1998; Guasch and Sabater, 1998), pH (Guasch et al., 2002) and nutrients like phosphorus (Serra et al., 2010) have been shown to modify periphyton tolerance levels. Therefore, the increase of tolerance measured along the Seine river has to be related to the global urban gradient (both metal concentrations and physico-chemical parameters).

Co-tolerance to metals is a well-known phenomenon in algal and bacterial species and has been observed for indoor-exposed periphyton (Fechner et al., 2011a; Soldo and Behra, 2000). It is therefore likely to occur 
also for in-situ exposed communities collected in an urban contamination gradient. In the present study, a significant increase of tolerance to $\mathrm{Cu}$ was observed from site 2 to site 3 although mean $\mathrm{Cu}$ concentrations in the river and biofilm-accumulated $\mathrm{Cu}$ concentrations were similar at both sites. Therefore, it is possible that exposure to metals other than $\mathrm{Cu}$ conferred tolerance to $\mathrm{Cu}$ for the site $3 \mathrm{biofilm}$. As regards $\mathrm{Ni}$, biofilm tolerance levels were similar for both downstream sites although the lowest biofilm-accumulated $\mathrm{Ni}$ level was observed for the site 2 biofilm. Therefore, the high Ni tolerance of the site 2 biofilm might also be related to co-tolerance to other metals: for instance mean total concentrations of $\mathrm{Cu}, \mathrm{Pb}, \mathrm{Zn}$ and $\mathrm{Cd}$ were higher at site 2 (compared to site 3). Therefore, it is not easy to link tolerance and exposure levels in a context of diffuse multi-contamination. Although tolerance acquisition was observed for several metals using the same methodlogy in controlled microcosm experiments (Fechner et al., 2011a), it is thus probable that, for in situ experiments, tolerance acquisition should be used to identify the global impact of urban pressure on communities and not to identify the impact of a specific toxic agent.

\section{Relevance of tolerance measurements using $\beta$-glucosidase activity to assess multi-metallic exposure}

$\beta$-glucosidase activity used as endpoint to measure community tolerance appeared to be a particularly sensitive biological variable to detect the impact of multi-metallic exposure. Indeed, no clear relationship was revealed between contamination levels and the other biofilm descriptors, whereas periphyton tolerance to $\mathrm{Cd}, \mathrm{Cu}, \mathrm{Ni}, \mathrm{Pb}$ and $\mathrm{Zn}$ increased along the river as already observed in a study focusing on biofilm tolerance to $\mathrm{Cu}$ (Fechner et al., 2011b). PCA confirmed the positive correlation between metal tolerance of natural biofilms and the metallic contamination. Moreover, the increase of tolerance to metals along the river is concomitant with changes in both eukaryotic and bacterial community structure as revealed by ARISA fingerprints. This observation showed that community tolerance was probably related to species composition. Indeed, disappearance of sensitive species during exposure is one of the phenomenons which leads to tolerance acquisition at the community level (Blanck, 2002). Although higher tolerance levels could also be related to acclimatization processes, the similar community structures observed for both downstream sites suggested that heterotrophic communities collected downstream from the urban area were different from the heterotrophic communities collected upstream. Increases of tolerance to metals (Cd and $\mathrm{Zn}$ ) had already been described in other field studies for natural bacterial communities using thymidine incorporation as the endpoint for tolerance measurements (Admiraal et al., 1999; Lehmann et al., 1999). Yet, biofilms were collected in highly-impacted areas, due to mining activity: even the upstream site was highly contaminated when compared to sites 2 and 3 of the present study. Indeed, in the present study, individual metal contamination levels remained very low. For instance, total $\mathrm{Zn}$ concentrations measured at sites 2 and 3 were lower than the range of concentrations monitored in the field study of Blanck et al. 
(2003). Community tolerance measurements using $\beta$-glucosidase activity as endpoint thus appear as good indicators of the biological impacts of a typical diffuse urban metallic exposure.

\section{Tolerance acquisition at low exposure levels}

It is noteworthy that an increase of biofilm tolerance to metals down the Seine river was actually detected despite low exposure levels. For instance, in a previous study using $\beta$-glucosidase activity measurements in microcosm experiments (Fechner et al., 2011a), no increase in tolerance acquisition was observed after a three-week exposure to $\mathrm{Zn}$ at $20 \mu \mathrm{g} / \mathrm{L}$. In contrast to those results, in the present study, Zn concentrations at downstream sites 2 and 3 were lower in the Seine river, and yet, the increase in Zn tolerance was significant (considering 95\% confidence intervals) after a similar exposure time. The higher sensitivity of natural periphyton (as opposed to laboratory-grown periphyton) could arise from a greater complexity of natural communities (Serra et al., 2009). There is also a possibility that metal-resistant bacteria present in biofilms collected at sites 2 and 3 could have been transported to the river by sewage or other contamination sources. This is especially true for site 3 which is located downstream from the effluent of a large sewage treatment plant. The difference in sensitivity could also be related to differences in metal speciation during exposure, as metal speciation might be very different from one study to another. As suggested by PCA, it is probable that labile and dissolved metals are better related to metal-induced tolerance than total metals, at least for some metals. DGT-labile metal concentrations have indeed been shown to provide good estimations of bioavailable metal concentrations to various aquatic organisms (Ferreira et al., 2008; 2009; Tusseau-Vuillemin et al., 2004). More recently, Bradac et al. (2010) showed that Cd-accumulation in periphyton may be controlled by either dissolved or DGT-labile Cd concentrations. But the relationship between DGT-labile metal concentrations and bioaccumulation or toxicity to periphyton remains to be investigated. Guasch et al. (2009) found that the metal content of periphyton collected in a field study accounted for a significant portion of diatom species variance in the biofilms. In the present study, although biofilm-accumulated metal concentrations are generally positively correlated with metal concentrations in the river water, complex mechanisms of metal accumulation in periphytic communities exposed in situ are brought to light. For instance, biofilm-accumulated Ni concentrations do not correspond to the gradient of $\mathrm{Ni}$ exposure measured in the field.

Another explanation to the difference of sensitivity between laboratory- or in situ-exposed biofilms could also be related to the mixture of micropollutants (both metallic and organic) in the Seine river. Mixture toxicity can indeed be observed even when the mixture components are present at low, non-significant effect concentrations (Arrhenius et al., 2004). Moreover, other typically urban micropolluants (for instance 
PAHs, PCBs, etc.), some of which had already been detected in the Seine river (Tusseau-Vuillemin et al., 2007), might exert a selection pressure leading to adaptation of biofilms to urban contamination, and thus to metals.

\section{Conclusions}

This study was designed as a first attempt to relate heterotrophic biofilm metal tolerance to diffuse urban contamination at low exposure levels using a short-term test based on $\beta$-glucosidase activity. The results showed that periphyton tolerance to $\mathrm{Cd}, \mathrm{Cu}, \mathrm{Zn}, \mathrm{Pb}$ and $\mathrm{Ni}$ increased upstream to downstream from the urban area of Paris (France) along the Seine river. Although the Seine river has long been subjected to metal contamination (Meybeck et al., 2007; Thévenot et al., 2007), current mean concentrations of dissolved metals in the water remained low when compared to either EQSs from the European Water Framework Directive or to National Recommended Water Quality Criteria from the US EPA (National Recommended Water Quality Criteria, 2009). Therefore, tolerance measurements at the community level are sensitive and environmentally relevant indicators of an urban disturbance, considered here both in terms of micropollutants and other physico-chemical parameters. Other authors have already pinpointed that, although they are based on ecotoxicological data, EQSs might not protect organisms at the community level (McClellan et al., 2008). The study thus supports the potential role of biofilms as sensitive indicators of urban pollution in aquatic ecosystems. Moreover, the results suggest that exposure to a mixture of contaminants at levels lower than quality standards might have a significant impact on periphytic communities.

\section{Acknowledgement}

This study was supported by ONEMA and is part of the SISTEO project from the Ile-de-France Regional Council. The authors would like to thank Emmanuelle Uher for her great help with metal analysis and Sophie Ayrault for providing access to the ICP-MS platform at the LSCE. They also thank Aurélie Germain and François Versace for their valuable help both in the field and laboratory, Julien Guieu for editing the English version of the manuscript and Renata Behra (Eawag,) for her precious advice on discussing the results. 


\section{References}

Admiraal, W., Blanck, H., Buckert-de Jong, M., Guasch, H., Ivorra, N., Lehmann, V., Nystrom, B.A.H., Paulsson, M., Sabater, S., 1999. Short-term toxicity of zinc to microbenthic algae and bacteria in a metal polluted stream. Water Research 33, 1989-1996.

Admiraal, W., Tubbing, D.M.J., 1991. Extracellular enzyme activity associated with suspended matter in the River Rhine. Freshwater Biology 26, 507-517.

Arrhenius, A., Grönvall, F., Scholze, M., Backhaus, T., Blanck, H., 2004. Predictability of the mixture toxicity of 12 similarly acting congeneric inhibitors of photosystem II in marine periphyton and epipsammon communities. Aquatic Toxicology 68, 351-367.

Beasley, G., Kneale, P.E., 2004. Assessment of heavy metal and PAH contamination of urban streambed sediments on macroinvertebrates. Water, Air, and Soil Pollution: Focus 4, 563-578.

Blanck, H., 2002. A Critical Review of Procedures and Approaches Used for Assessing Pollution-Induced Community Tolerance (PICT) in Biotic Communities. Human and Ecological Risk Assessment 8, 10031034.

Blanck, H., Admiraal, W., Cleven, R.F.M.J., Guasch, H., Hoop, M.A.G.T.v.d., Ivorra, N., Nyström, B., Paulsson, M., Petterson, R.P., Sabater, S., Tubbing, G.M.J., 2003. Variability in Zinc Tolerance, Measured as Incorporation of Radio-Labeled Carbon Dioxide and Thymidine, in Periphyton Communities Sampled from 15 European River Stretches. Archives of Environmental Contamination and Toxicology 44, 17-29.

Blanck, H., Eriksson, K.M., Grönvall, F., Dahl, B., Guijarro, K.M., Birgersson, G., Kylin, H., 2009. A retrospective analysis of contamination and periphyton PICT patterns for the antifoulant irgarol 1051, around a small marina on the Swedish west coast. Marine Pollution Bulletin 58, 230-237.

Blanck, H., Wängberg, S.-A., Molander, S., 1988. Pollution-Induced Community Tolerance - a new ecotoxicological tool, in: Cairns, J.J., Pratt, J.R. (Eds.), Functional Testing of Aquatic Biota for Estimating Hazards of Chemicals. American Society for Testing and Materials, Philadelphia, PA, USA, pp. 219-230.

Bourgeault, A., Gourlay-Francé, C., Vincent-Hubert, F., Palais, F., Geffard, A., Biagianti-Risbourg, S., PainDevin, S., Tusseau-Vuillemin, M.H., 2010. Lessons from a transplantation of zebra mussels into a small urban river: An integrated ecotoxicological assessment. Environmental Toxicology 25, 468-478.

Bradac, P., Wagner, B., Kistler, D., Traber, J., Behra, R., Sigg, L., 2010. Cadmium speciation and accumulation in periphyton in a small stream with dynamic concentration variations. Environmental Pollution 158, 641-648.

Cardinale, M., Brusetti, L., Quatrini, P., Borin, S., Puglia, A.M., Rizzi, A., Zanardini, E., Sorlini, C., Corselli, C., Daffonchio, D., 2004. Comparison of Different Primer Sets for Use in Automated Ribosomal Intergenic Spacer Analysis of Complex Bacterial Communities. Appl. Environ. Microbiol. 70, 6147-6156.

Chrost, R.J., 1991. Microbial Enzymes in Aquatic Environments.

Clarke, K.R., 1993. Non-parametric multivariate analyses of changes in community structure. Australian Journal of Ecology 18, 117-143.

Clements, W.H., Carlisle, D.M., Courtney, L.A., Harrahy, E.A., 2002. Integrating observational and experimental approaches to demonstrate causation in stream biomonitoring studies. Environmental Toxicology and Chemistry 21, 1138-1146.

Clements, W.H., Rohr, J.R., 2009. Community responses to contaminants: using basic ecological principles to predict ecotoxicological effects Environmental Toxicology and Chemistry 28, 1789-1800.

Fechner, L.C., Gourlay-Francé, C., Tusseau-Vuillemin, M.H., 2011a. Low exposure levels of urban metals induce heterotrophic community tolerance: a microcosm validation. Ecotoxicology 20, 793-802.

Fechner, L.C., Gourlay-Francé, C., Uher, E., Tusseau-Vuillemin, M.H., 2010a. Adapting an enzymatic toxicity test to allow comparative evaluation of natural freshwater biofilms' tolerance to metals. Ecotoxicology 19, 1302-1311.

Fechner, L.C., Versace, F., Gourlay-Francé, C., Tusseau-Vuillemin, M.H., 2011b. Adaptation of copper community tolerance levels after biofilm transplantation in an urban river. Aquatic Toxicology doi:10.1016/j.aquatox.2011.09.019. 
Fechner, L.C., Vincent-Hubert, F., Gaubert, P., Bouchez, T., Gourlay-Francé, C., Tusseau-Vuillemin, M.H., 2010b. Combined eukaryotic and bacterial community fingerprinting of natural freshwater biofilms using Automated Ribosomal Intergenic Spacer Analysis. Fems Microbiology Ecology 74, 542-553.

Ferreira, D., Tousset, N., Ridame, C., Tusseau-Vuillemin, M.H., 2008. More than inorganic copper is bioavailable to aquatic mosses at environmentalaay relevant concentrations. Environmental Toxicology and Chemistry 27, 2108-2116.

Guasch, H., Ivorra, N., Lehmann, V., Paulsson, M., Real, M., Sabater, S., 1998. Community composition and sensitivity of periphyton to atrazine in flowing waters: the role of environmental factors. Journal of Applied Phycology 10, 203-213.

Guasch, H., Leira, M., Montuelle, B., Geiszinger, A., Roulier, J.L., Tornes, E., Serra, A., 2009. Use of multivariate analyses to investigate the contribution of metal pollution to diatom species composition: Search for the most appropriate cases and explanatory variables. Hydrobiologia 627, 143-158.

Guasch, H., Paulsson, M., Sabater, S., 2002. Effect of copper on algal communities from oligotrophic calcareous streams. Journal of Phycology 38, 241-248.

Guasch, H., Sabater, S., 1998. Light history influences the sensitivity to atrazine in periphytic algae. Journal of Phycology 34, 233-241.

Hill, A.V., 1910. The possible effects of the aggregation of the molecules of haemoglobin on its dissociation curves. Journal of Physiology 40, iv-vii.

Lear, G., Lewis, G.D., 2009. Impact of catchment land use on bacterial communities within stream biofilms. Ecological Indicators 9, 848-855.

Lehmann, V., Tubbing, G.M.J., Admiraal, W., 1999. Induced Metal Tolerance in Microbenthic Communities from Three Lowland Rivers with Different Metal Loads. Archives of Environmental Contamination and Toxicology 36, 384-391.

McClellan, K., Altenburger, R., Schmitt-Jansen, M., 2008. Pollution-induced community tolerance as a measure of species interaction in toxicity assessment. Journal of Applied Ecology 45, 1514-1522.

Meybeck, M., 2003. Global analysis of river systems: From Earth system controls to Anthropocene syndromes. Philosophical Transactions of the Royal Society B: Biological Sciences 358, 1935-1955.

Meybeck, M., Lestel, L., Bonté, P., Moilleron, R., Colin, J.L., Rousselot, O., Hervé, D., de Pontevès, C., Grosbois, C., Thévenot, D.R., 2007. Historical perspective of heavy metals contamination (Cd, $\mathrm{Cr}, \mathrm{Cu}, \mathrm{Hg}$, $\mathrm{Pb}, \mathrm{Zn}$ ) in the Seine River basin (France) following a DPSIR approach (1950-2005). Science of The Total Environment 375, 204-231.

Michelland, R.J., Dejean, S., Combes, S., Fortun-Lamothe, L., Cauquil, L., 2009. StatFingerprints: a friendly graphical interface program for processing and analysis of microbial fingerprint profiles. Molecular Ecology Resources 9, 1359-1363.

National Recommended Water Quality Criteria, U.S.E.P.A., 2009. Office of Water, Office of Science and Technology http://www.epa.gov/ost/criteria/wqctable.

Pesce, S., Margoum, C., Montuelle, B., 2010. In situ relationships between spatio-temporal variations in diuron concentrations and phototrophic biofilm tolerance in a contaminated river. Water Research 44, 1941-1949.

Priadi, C., Ayrault, S., Pacini, S., Bonte, P., 2011. Urbanization impact of the Greater Paris Region on metal mobility in suspended sediments in the Seine River, France: Role of metal oxides International Journal of Environmental Science and Technology 8, 1-18.

Priadi, C., Bourgeault, A., Ayrault, S., Gourlay-Francé, C., Tusseau-Vuillemin, M.H., 2010. How does urbanization affect metal solid-solution partitioning? Dissolved - DGT - particulate fraction. in prep.

Ranjard, L., Poly, F., Lata, J.C., Mougel, C., Thioulouse, J., Nazaret, S., 2001. Characterization of Bacterial and Fungal Soil Communities by Automated Ribosomal Intergenic Spacer Analysis Fingerprints: Biological and Methodological Variability. Appl. Environ. Microbiol. 67, 4479-4487.

Sabater, S., Guasch, H., Ricart, M., Romaní, A., Vidal, G., Klünder, C., Schmitt-Jansen, M., 2007. Monitoring the effect of chemicals on biological communities. The biofilm as an interface. Analytical and Bioanalytical Chemistry 387, 1425-1434.

Serra, A., Corcoll, N., Guasch, H., 2009. Copper accumulation and toxicity in fluvial periphyton: The influence of exposure history. Chemosphere 74, 633-641. 
Serra, A., Guasch, H., Admiraal, W., Van Der Geest, H.G., Van Beusekom, S.A.M., 2010. Influence of phosphorus on copper sensitivity of fluvial periphyton: The role of chemical, physiological and communityrelated factors. Ecotoxicology 19, 770-780.

Soldo, D., Behra, R., 2000. Long-term effects of copper on the structure of freshwater periphyton communities and their tolerance to copper, zinc, nickel and silver. Aquatic Toxicology 47, 181-189.

Thévenot, D.R., Moilleron, R., Lestel, L., Gromaire, M.-C., Rocher, V., Cambier, P., Bonté, P., Colin, J.-L., de Pontevès, C., Meybeck, M., 2007. Critical budget of metal sources and pathways in the Seine River basin (1994-2003) for Cd, Cr, Cu, Hg, Ni, Pb and Zn. Science of The Total Environment 375, 180-203.

Tusseau-Vuillemin, M.-H., Gourlay, C., Lorgeoux, C., Mouchel, J.-M., Buzier, R., Gilbin, R., Seidel, J.-L., Elbaz-Poulichet, F., 2007. Dissolved and bioavailable contaminants in the Seine river basin. Science of The Total Environment 375, 244-256.

Tusseau-Vuillemin, M.H., Gilbin, R., Bakkaus, E., Garric, J., 2004. Performance of diffusion gradient in thin films to evaluate the toxic fraction of copper to Daphnia magna. Environmental Toxicology and Chemistry 23, 2154-2161.

Vindimian, E., 2001. REGTOX: The solution for dose-response modeling with Exel, p. http://www.normalesup.org/ vindimian/DOC en web/doc en 2.htm.

Zhang, H., Davison, W., 1995. Performance Characteristics of Diffusion Gradients in Thin Films for the in Situ Measurement of Trace Metals in Aqueous Solution. Analytical Chemistry 67, 3391 -3400. 
Figure 1. Histograms of mean total (a), dissolved (b) and labile (c) metal concentrations in the Seine river at sites 1,2 and 3 over the period corresponding to the experiment $(\mathrm{n}=3)$. Error bars show standard deviations $( \pm \sigma)$. The labile metal concentrations were determined by the means of sets of 3 DGTs immersed at each site. Means and $\sigma$ were calculated on three samplings performed between May and July 2009. For Cd, Zn, Mn and Ag, metal concentrations were multiplied by factors indicated in the histograms for more clarity. A* indicates a significant statistical difference between site 2 or 3 and site 1 (Kruskal Wallis: $\mathrm{p}<0.1$ and Dunn tests, $\mathrm{p} \leq 0.05)$.

a

Total metal $(\mu \mathrm{g} / \mathrm{L})$

b

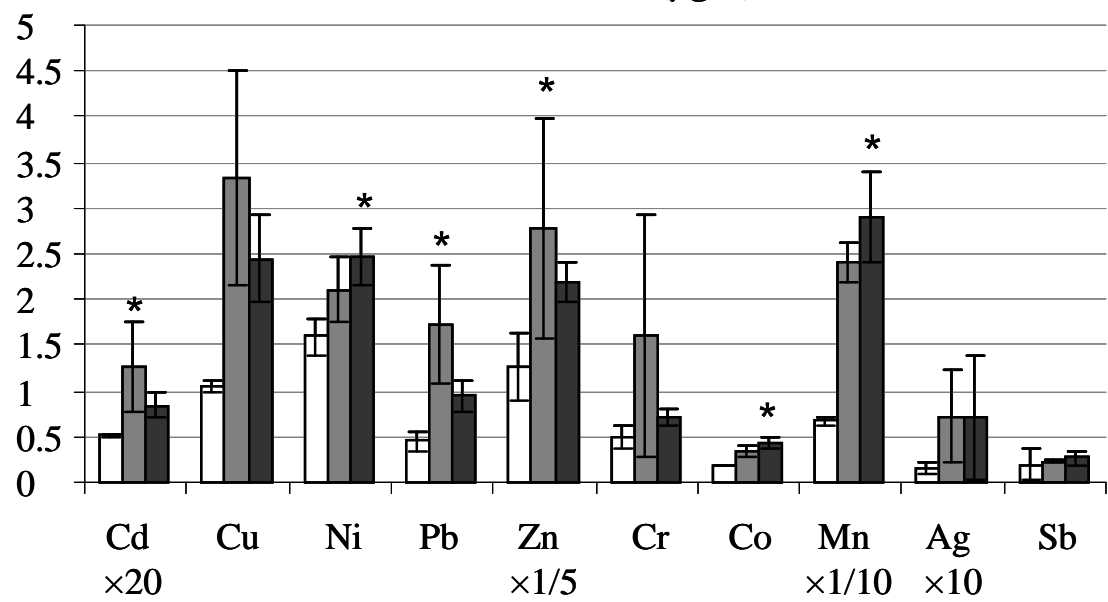

Dissolved metal $(\mu \mathrm{g} / \mathrm{L})$

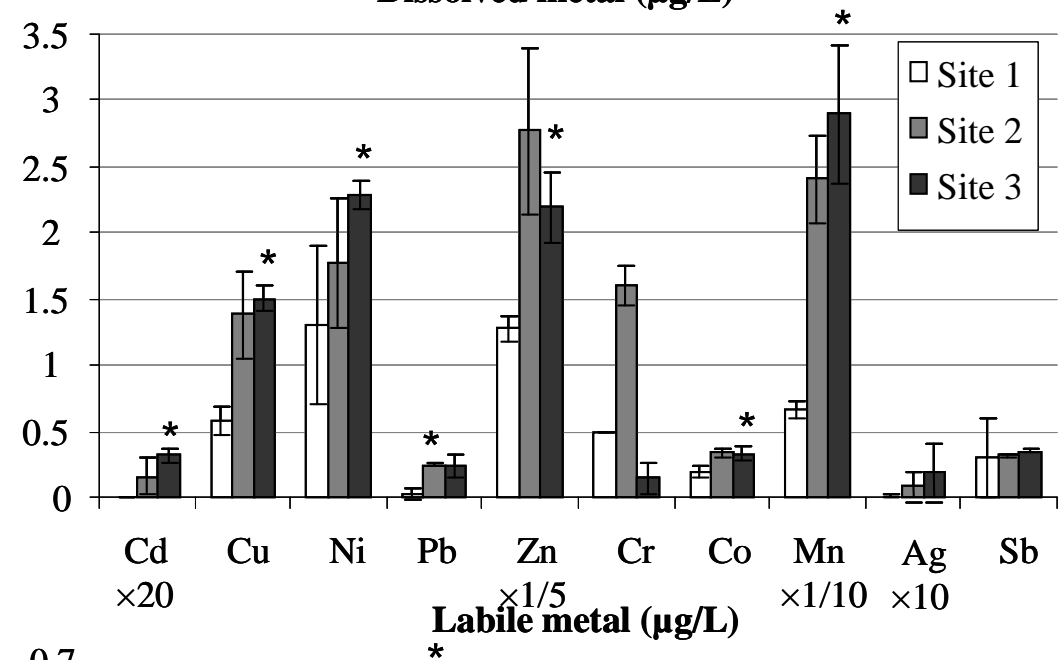

c

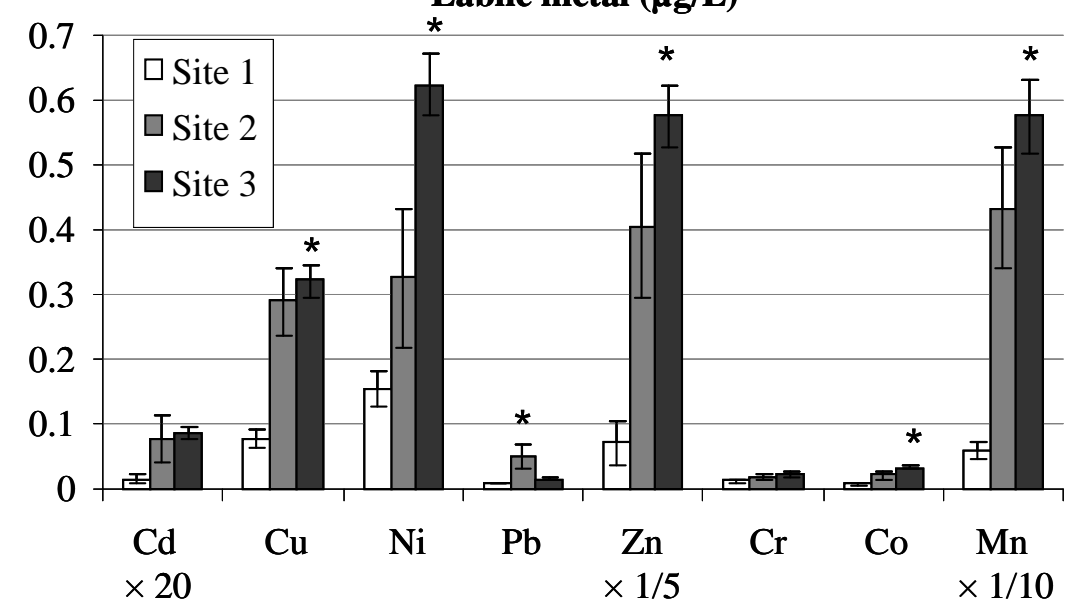


Figure 2. PCA plot of environmental (metallic and physico-chemical parameters) and biofilm (tolerance values and biofilm gross descriptors) parameters. a: correlation circle. b: score plot showing the three sites. Abbreviations ared use for more clarity: lab for labile, dis for dissolved and tot for total metal concentrations. Biological parameters are shown in bold letters and physico-chemical parameters in italics.

a.

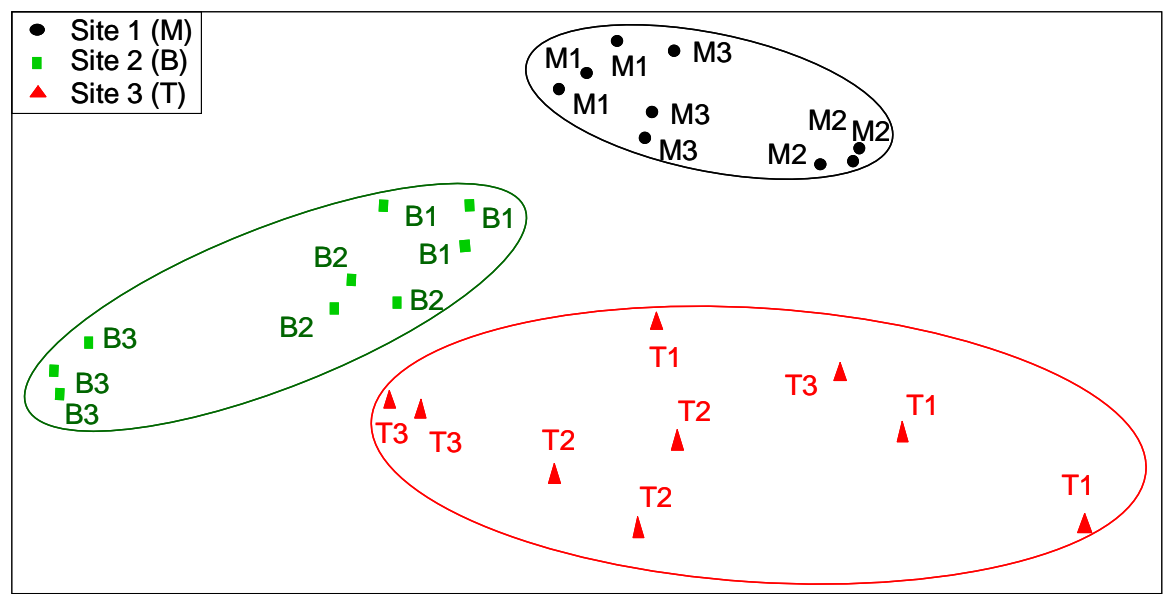

(bacteria)

b.

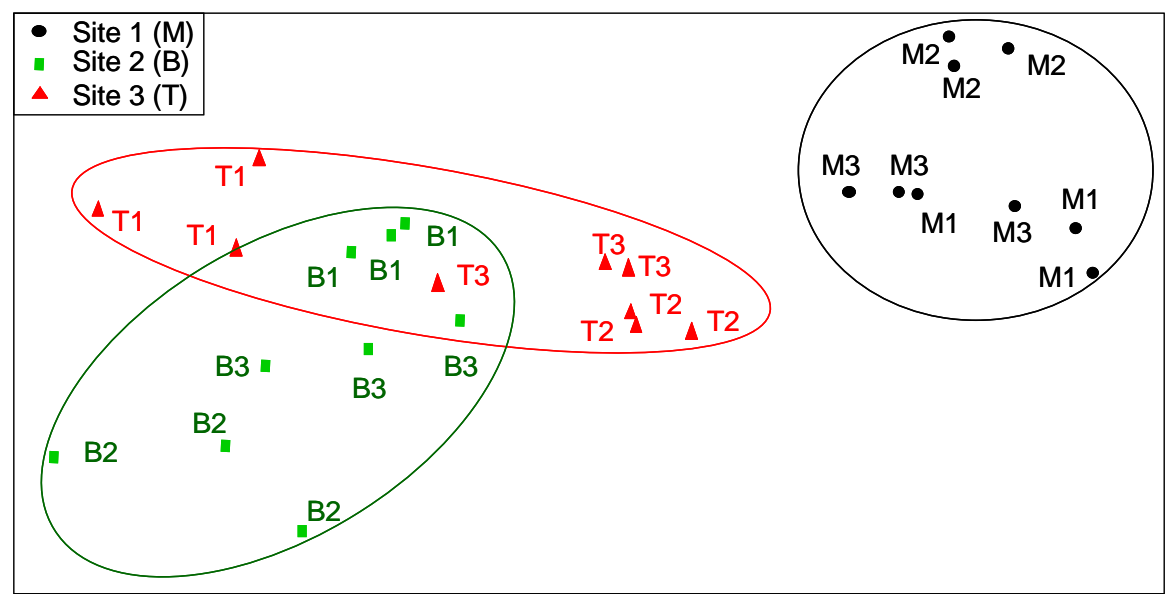

(set 'euk')

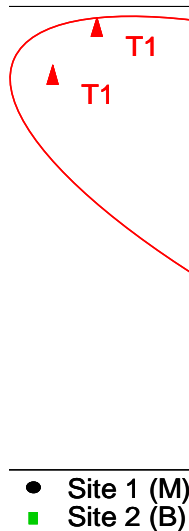

(set 'diat') 
Figure 3. Non-metric multidimensional scaling plots derived from the Euclidian distances between ARISA fingerprints obtained using StatFingerprints. 2D stress is respectively 0.10, 0.10 and 0.07 for respectively a) bacterial ARISA; b) eukaryotic ARISA performed using set euk for PCR amplification and c) eukaryotic ARISA performed using set diat for PCR amplification. Samples collected on day 28, 35 and 42 are referred to as "1", "2" and "3" respectively. Biofilms were collected in triplicates.

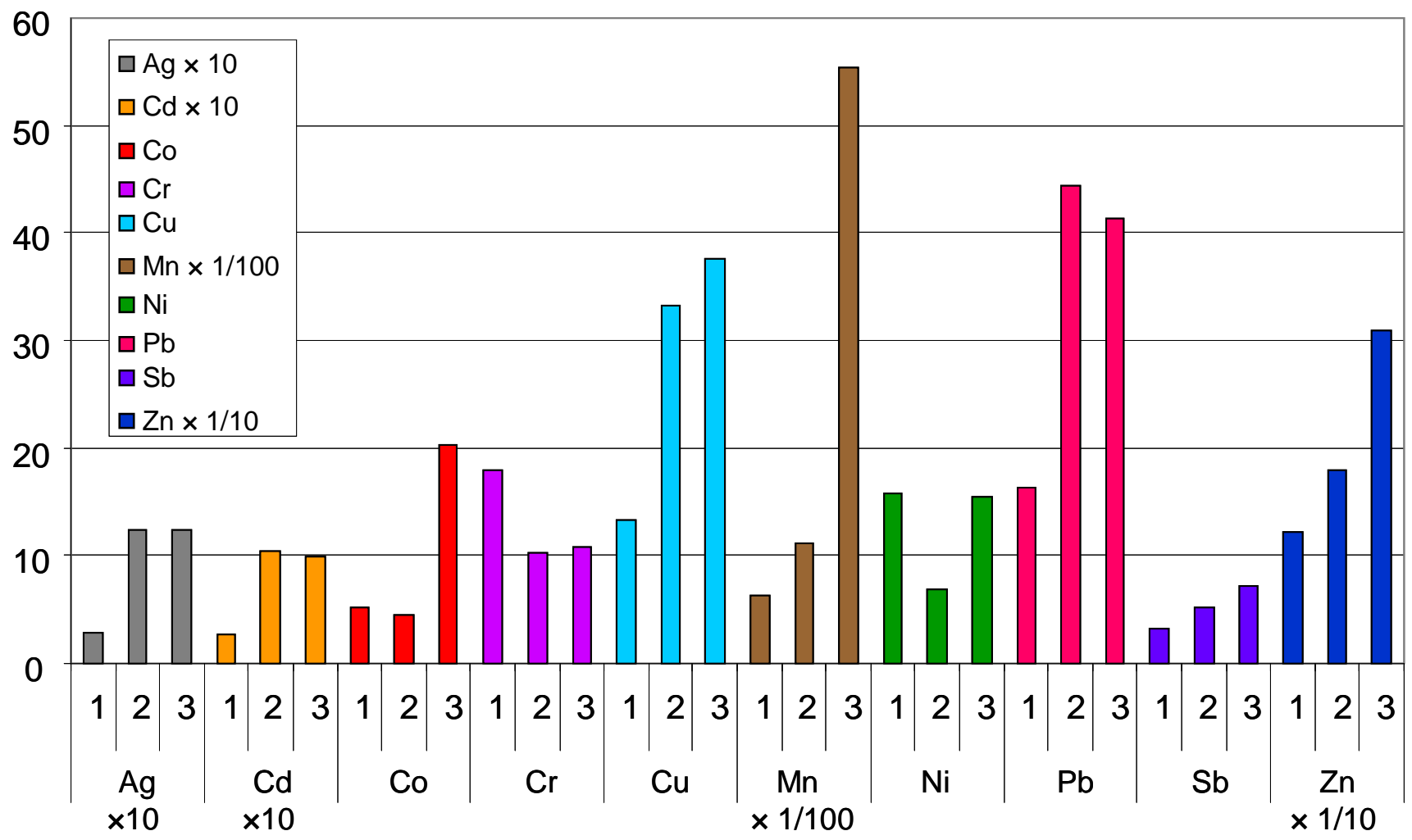


Figure 4. Concentrations of metals accumulated within periphyton from the three sites (each site is indicated by its number e.g. "1" for site 1). Concentrations are expressed in $\mu g$ metal/g of biofilm dry weight and were multiplied by a factor indicated in the legend for $\mathrm{Ag}, \mathrm{Cd}, \mathrm{Mn}$ and $\mathrm{Zn}$ for more clarity.
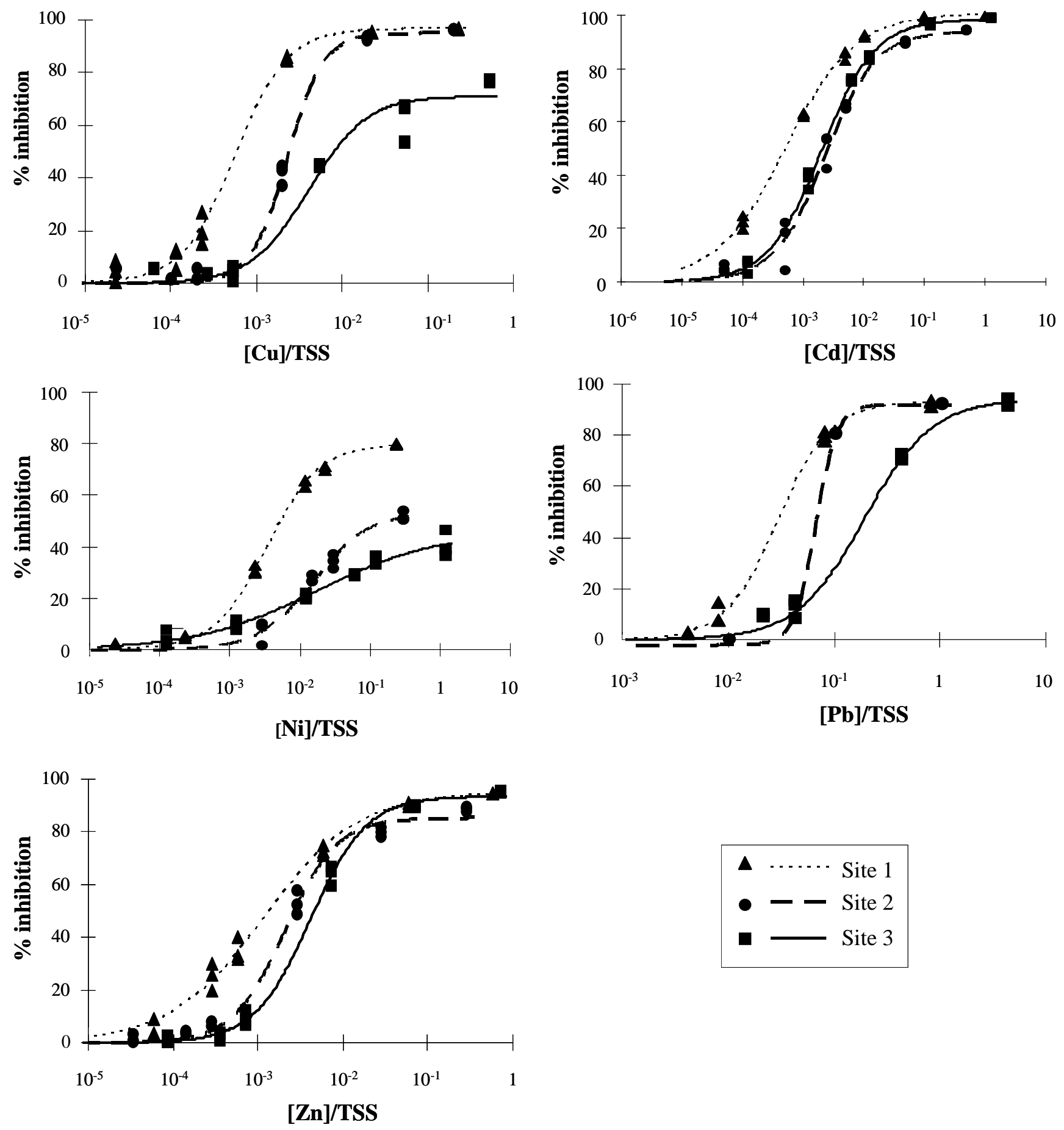
Figure 5. Dose/effect curves obtained with the $\beta$-glucosidase toxicity tests performed on the biofilms collected at the three sites with $\mathrm{Cu}, \mathrm{Cd}, \mathrm{Ni}, \mathrm{Pb}$ and $\mathrm{Zn} . \%$ inhibition values are shown as $\boldsymbol{\Delta}$ for the biofilms collected at site 1 (dotted line), as $\bullet$ for the biofilm collected at site 2 (dashed line) and as $\boldsymbol{\square}$ for the biofilm collected at site 3 (full line). For each metal concentration tested, \% inhibition of $\beta$-glucosidase activity are shown as triplicates. TSS-normalized metal concentrations are expressed as $g_{\text {metal }} / g_{\text {TSS. }}$

a.

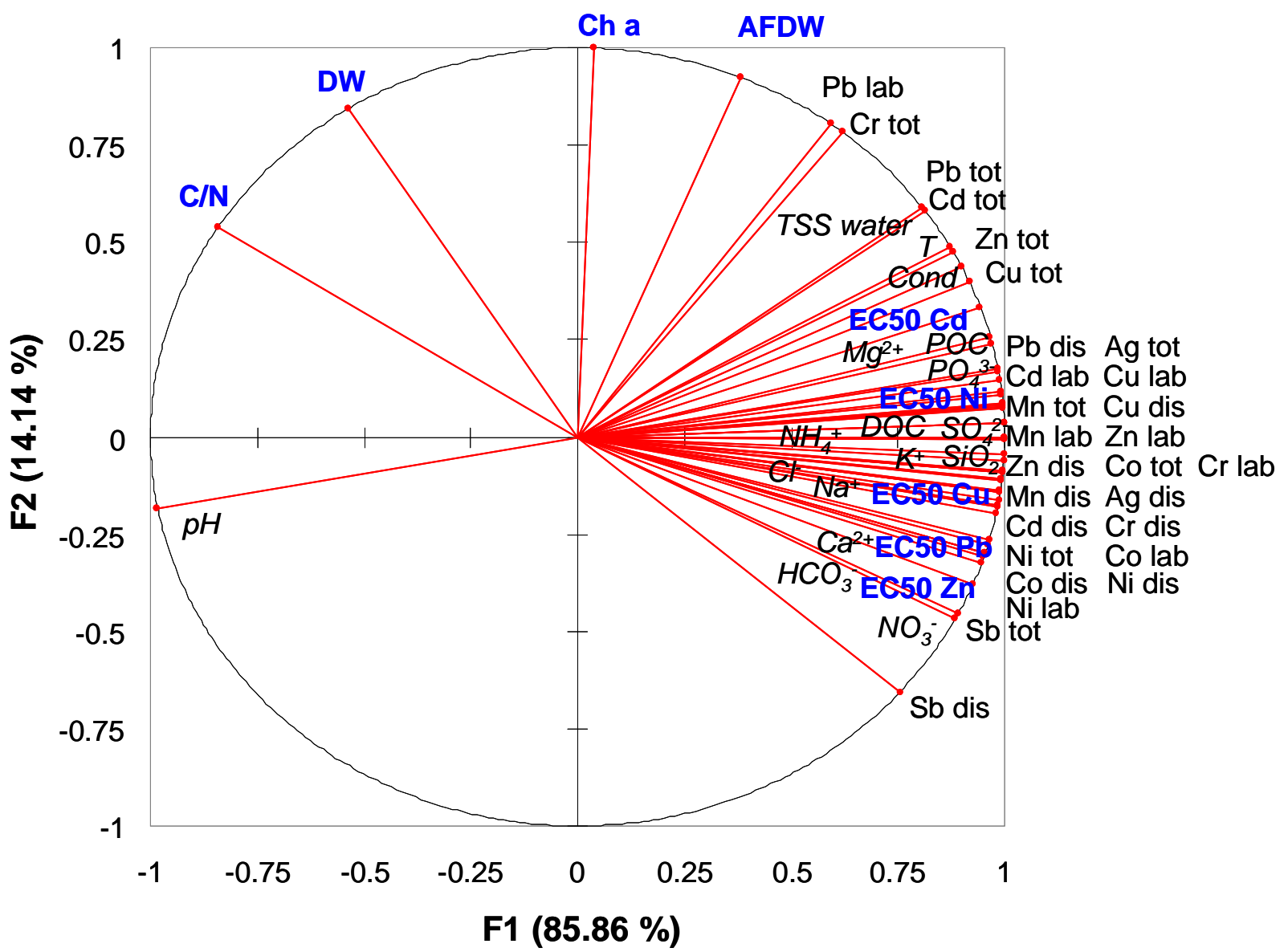


b.

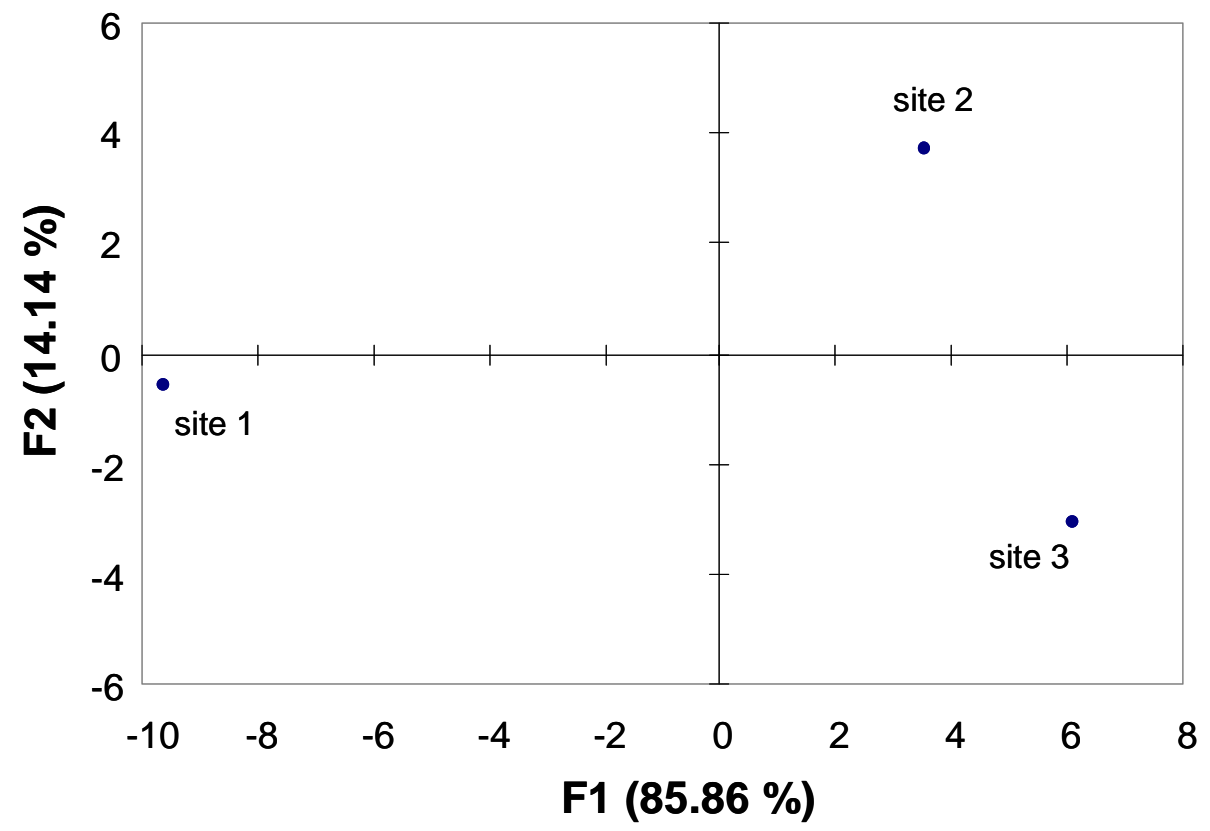


Table 1. Environmental Quality Standards from the European Water Framework Directive (for waters with $\mathrm{CaCO}_{3}>200 \mathrm{mg} / \mathrm{L}$ ), means and standard deviations of dissolved metal concentrations measured at the three sites during the experiment (means of three individual samplings between May and July 2009) for Cd, $\mathrm{Ni}, \mathrm{Pb}, \mathrm{Zn}$ and $\mathrm{Cu}$. Concentrations are expressed in $\mu \mathrm{g} / \mathrm{L}$.

\begin{tabular}{|c|c|ccc|}
\hline metal & EQS & site 1 & site 2 & site 3 \\
& & & & \\
\hline $\mathrm{Cd}$ & 0.25 & $0^{*}$ & $0.008( \pm 0.007)$ & $0.015( \pm 0.003)$ \\
$\mathrm{Ni}$ & 20 & $1.30( \pm 0.60)$ & $1.77( \pm 0.49)$ & $2.29( \pm 0.11)$ \\
$\mathrm{Pb}$ & 7.2 & $0.02( \pm 0.04)$ & $0.24( \pm 0.01)$ & $0.23( \pm 0.09)$ \\
$\mathrm{Zn}$ & 7.8 & $2.32( \pm 0.43)$ & $6.51( \pm 3.11)$ & $8.02( \pm 1.37)$ \\
$\mathrm{Cu}$ & 1.4 & $0.58( \pm 0.11)$ & $1.38( \pm 0.33)$ & $1.50( \pm 0.10)$ \\
\hline
\end{tabular}

* Dissolved Cd concentrations measured at site 1 were either below the detection (first two samplings) or quantification (third sampling) limits. 
Table 2. Mean values and corresponding standard deviations ( $\sigma$ ) of dry weights (DW), ash-free dry weights (AFDW), Chl-a concentrations and $\mathrm{C} / \mathrm{N}$ ratios corresponding to the biofilms collected on the three sites ( $\mathrm{n}=9$ as each parameter was measured in triplicate at each sampling date). A * indicates a significant statistical difference between sampling sites (Kruskal Wallis and Dunn tests, $\mathrm{p}<0.05$ ).

\begin{tabular}{|c|c|c|c|}
\hline \multirow{2}{*}{ biofilm parameters } & \multirow{2}{*}{ sites } & \multicolumn{2}{|c|}{$\begin{array}{c}\text { over the three sampling } \\
\text { dates }\end{array}$} \\
\hline & & mean & $\sigma$ \\
\hline \multirow{3}{*}{$\mathrm{DW}\left(\mathrm{mg} / \mathrm{cm}^{2}\right)$} & 1 & 3.60 & 1.03 \\
\hline & 2 & 4.18 & 0.77 \\
\hline & 3 & $1.23 *$ & 0.31 \\
\hline \multirow{3}{*}{$\mathrm{AFDW}\left(\mathrm{mg} / \mathrm{cm}^{2}\right)$} & 1 & 0.61 & 0.16 \\
\hline & 2 & $1.59 *$ & 0.27 \\
\hline & 3 & 0.63 & 0.18 \\
\hline \multirow{3}{*}{ Chl- $a\left(\mathrm{mg} / \mathrm{m}^{2}\right)$} & 1 & 32.85 & 14.40 \\
\hline & 2 & $79.80 *$ & 27.25 \\
\hline & 3 & 21.15 & 9.30 \\
\hline \multirow{3}{*}{$\mathrm{C} / \mathrm{N}$ ratio } & 1 & 6.93 & 0.25 \\
\hline & 2 & 6.52 & 0.30 \\
\hline & 3 & $5.76 *$ & 0.18 \\
\hline
\end{tabular}


Table 3. Normalized $\mathrm{EC}_{50}$ values ( $\mathrm{mg}_{\mathrm{metal}} / \mathrm{g}_{\mathrm{TSS}}$ ) and maximum percentages of inhibition obtained with the dose effect curves. 95\% confidence intervals are shown in brackets.

\begin{tabular}{|c|c|c|c|c|}
\hline metal & biological response & site 1 & site 2 & site 3 \\
\hline \multirow{2}{*}{$\mathrm{Cu}$} & $\mathrm{EC}_{50} / \mathrm{TSS}$ & $0.54( \pm 0.12)$ & $2.16( \pm 0.27)$ & $3.65( \pm 2.49)$ \\
\hline & $\% \max$ & $96.3(95.8-96.9)$ & $95.8(94.4-97.6)$ & $74.0(67.8-80.4)$ \\
\hline \multirow{2}{*}{$\mathrm{Cd}$} & $\mathrm{EC}_{50} / \mathrm{TSS}$ & $0.47( \pm 0.04)$ & $2.13( \pm 0.33)$ & $1.84( \pm 0.22)$ \\
\hline & $\% \max$ & $100.6(99.7-101.5)$ & $93.5(91.7-95.8)$ & $98.4(97.6-99.2)$ \\
\hline \multirow{2}{*}{$\mathrm{Ni}$} & $\mathrm{EC}_{50} / \mathrm{TSS}$ & $3.17( \pm 0.46)$ & $14.63( \pm 5.45)$ & $16.69( \pm 179.97)$ \\
\hline & $\% \max$ & $79.1(77.2-81.1)$ & $54.9(50.0-60.0)$ & $44.6(38.5-68.2)$ \\
\hline \multirow{2}{*}{$\mathrm{Pb}$} & $\mathrm{EC}_{50} / \mathrm{TSS}$ & $27.12( \pm 4.33)$ & $80.36( \pm 5.17)$ & $170.85( \pm 42.60)$ \\
\hline & $\% \max$ & $92.8(91.0-94.5)$ & $92.1(91.7-92.4)$ & $89.9(88.4-91.7)$ \\
\hline \multirow{2}{*}{$\mathrm{Zn}$} & $\mathrm{EC}_{50} / \mathrm{TSS}$ & $1.12( \pm 0.21)$ & $2.10( \pm 0.54)$ & $4.11( \pm 0.55)$ \\
\hline & $\% \max$ & 95.9 (94.6-97.4) & $87.6(82.9-90.9)$ & 95.1 (91.9-98.6) \\
\hline
\end{tabular}

